JPE 11-4-28

\title{
Z-Source Inverter with SiC Power Semiconductor Devices for Fuel Cell Vehicle Applications
}

\author{
M. Ghasem Hosseini Aghdam ${ }^{\dagger}$ \\ ${ }^{\dagger}$ Research and Development Center, Huawei Technologies Sweden AB, Stockholm, Sweden
}

\begin{abstract}
Power electronics is a key technology for electric, hybrid, plug-in hybrid, and fuel cell vehicles. Typical power electronics converters used in electric drive vehicles include dc/dc converters, inverters, and battery chargers. New semiconductor materials such as silicon carbide $(\mathrm{SiC})$ and novel topologies such as the Z-source inverter (ZSI) have a great deal of potential to improve the overall performance of these vehicles. In this paper, a Z-source inverter for fuel cell vehicle application is examined under three different scenarios. 1. a ZSI with Si IGBT modules, 2. a ZSI with hybrid modules, Si IGBTs/SiC Schottky diodes, and 3. a ZSI with SiC MOSFETs/SiC Schottky diodes. Then, a comparison of the three scenarios is conducted. Conduction loss, switching loss, reverse recovery loss, and efficiency are considered for comparison. A conclusion is drawn that the SiC devices can improve the inverter and inverter-motor efficiency, and reduce the system size and cost due to the low loss properties of SiC devices. A comparison between a ZSI and traditional PWM inverters with SiC devices is also presented in this paper. Based on this comparison, the Z-source inverter produces the highest efficiency.
\end{abstract}

Key Words: Fuel cell vehicle, Si and SiC power semiconductor devices, Traditional PWM inverter, Z-source inverter (ZSI)

\section{INTRODUCTION}

Advanced electric drive vehicles such as hybrid electric vehicles, plug-in hybrid electric vehicles, fuel cell electric vehicles, and pure electric vehicles, require power electronics to function. As a result, power electronics play a key role in the success of electric drive vehicles [1], [2]. Typical power electronics converters in electric drive vehicles include unidirectional and bidirectional dc/dc converters, three-phase inverters and battery chargers. There are various topologies depending on the vehicle version and car makers' choices.

Power modules represent more than 50\% of the power electronics cost in electric drive vehicles. Therefore, the development of new power devices is a critical aspect for power conversion applications along with novel topologies and control methods. Since $\mathrm{SiC}$ is a wide bandgap semiconductor, $\mathrm{SiC}$ devices have a lower specific on-state resistance and can operate at high temperature. $\mathrm{SiC}$ devices also have excellent reverse recovery characteristics and can be switched at higher frequencies than their Si counterparts [3]-[5]. Therefore, SiC devices are expected to replace the $\mathrm{Si}$ devices in highvoltage, high-temperature and high-frequency applications. Many power semiconductor devices have been proposed for $\mathrm{SiC}$, but only $\mathrm{SiC}$ Schottky diodes are commercially available up to $1700 \mathrm{~V} / 25 \mathrm{~A}, 1200 \mathrm{~V} / 50 \mathrm{~A}, 650 \mathrm{~V} / 10 \mathrm{~A}$, and $600 \mathrm{~V} / 20$

\footnotetext{
Manuscript received Dec. 18, 2010; revised Mar. 25, 2011

Recommended for publication by Associate Editor Chong-Man Yun.

$\dagger$ Corresponding Author: ghasem.aghdam@ @uawei.com

Tel: +46-8-1206 0808, Fax: +46-8-1206 0800, Huawei Technologies Sweden $\mathrm{AB}$

Research and Development Center, Huawei Technologies Sweden AB, Sweden
}

A. To date, SiC-based controllable switches, however, have only been available as research samples [4], [6]-[9].

Because of the wide speed range for constant power operation in fuel cell vehicles (FCVs), the electric motor and the inverter need to be oversized. A Z-source inverter could be an excellent solution for this application through efficiency, cost and reliability improvements [10]-[14]. A Z-source inverter uses a unique impedance circuit to couple the inverter main circuit to the power source that cannot be seen in the conventional inverters where capacitors and inductors are used [10]-[14].

This paper presents a $\mathrm{Z}$-source inverter with $\mathrm{SiC}$ power semiconductor devices for FCV applications. The paper is organized as follows: In Section II the basic configuration of the system and the control system are briefly described. In Section III the power losses of the ZSI are analytically modeled. In Section IV the ZSI is examined in three different scenarios: 1. conventional Si IGBT modules, 2. hybrid modules, Si IGBTs/SiC Schottky diodes, and 3. SiC MOSFETs/SiC Schottky diodes. The losses and efficiency of the three designed inverters are evaluated in Section V. Finally, a comparison between a conventional inverter and the ZSI with $\mathrm{SiC}$ devices is presented in Section VI.

\section{System CONFIGURATIONS AND CONTROL}

Fuel cell vehicles have the potential to significantly reduce dependence on oil and harmful emissions that cause climate change. For fuel cell vehicle (FCV) traction, electric motors require high voltage at high speed and high power. Therefore, the inverter and motor are usually oversized to meet the high 
power and high speed needs if a conventional three-phase inverter is employed as a power electronics converter. In order to overcome these problems in conventional voltage-source inverters, a Z-source inverter is used. Fig. 1 shows the traction drive system configuration of a Z-source inverter for FCVs. It consists of a fuel cell stack, an impedance network, a three-phase inverter and a three-phase motor. The Z-source inverter employs a unique impedance network coupled with the inverter main circuit to the power source. The dc voltage fed to the impedance network, consists of two equal inductors and two equal capacitors. The network inductors are connected in series arms and the capacitors are connected in diagonal arms. Compared with a traditional voltage-source inverter, the Z-source inverter has an extra switching state: the shootthrough state, as can be seen in Fig. 2 [10]-[14]. During the shoot-though state, the output voltage to the load terminals is zero, which is the same as the traditional zero states. Therefore, to maintain a sinusoidal output voltage, the activestate duty ratio has to be maintained and some or all of the zero states have to be turned into a shoot-through state. The Z-source network makes the shoot-through zero state possible. This network also act as a second order filter and it should required less inductance and less capacitance. The shootthrough zero state provides the unique buck-boost feature to the inverter dependent on the value of the boost factor [10]-[14]. Fig. 2 shows the carrier-based PWM technique with shoot-through zero states in order to control the Zsource inverter. In every switching cycle, two shoot-through zero states are used along with two adjacent active states to synthesize a desired voltage. It should be noted that each phase leg still switches on and off once per switching cycle. Without changing the total zero-state time interval, the shoot-through zero states are evenly allocated into each phase. That is, the active states are unchanged. However, the equivalent dc-link voltage to the inverter is boosted because of the shoot-through states. The detailed relationship is analyzed in [10]-[14].

\section{Modeling of Semiconductor Power Losses of THE ZSI}

The losses of a switching device can be divided into three parts: the off-state loss, the conduction loss and the switching loss. The leakage current during the off-state is negligibly small therefore the power losses during this state can be neglected. As a result, only conduction and switching losses are usually considered.

The transistor and diode currents, and thus the power losses depend a great deal on the modulation techniques used for the inverter. In the carrier-based sinusoidal PWM scheme, the six switches of a traditional inverter are treated as three independent phases and each phase is pulse width modulated by a sine wave function. The duty cycle of the pulse waveform varies over a longer period of the sine wave. This effectively produces sine wave voltages on all three phases that may be varied in both amplitude and frequency.

Under constant frequency conditions the duty cycle can be simplified in terms of the phase angle $\theta$.

$$
d(t)=\frac{1}{2}\left[1+m_{a} \sin (\theta)\right]
$$

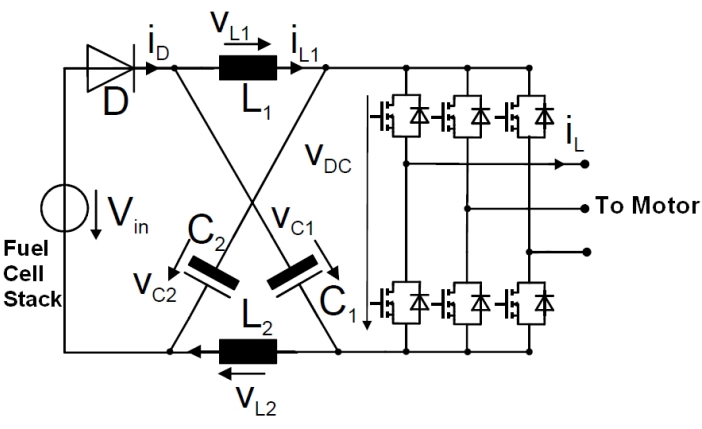

Fig. 1. Power circuit of Z-source inverter.

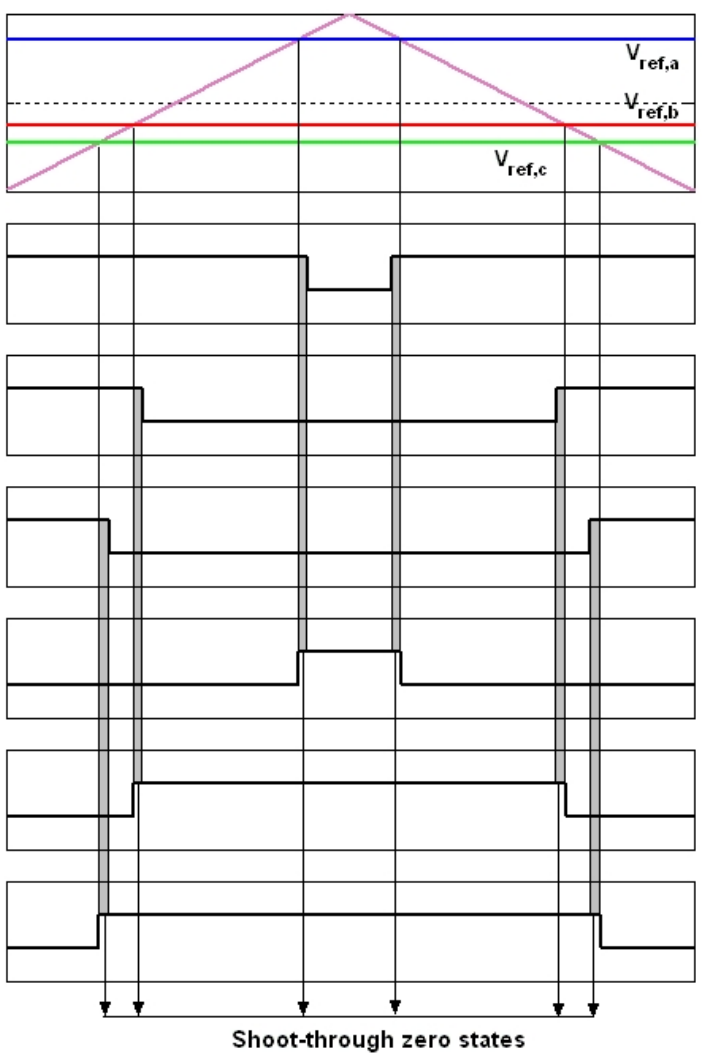

Fig. 2. Carrier-based PWM with shoot-through zero states.

where $m_{a}$ is the modulation index.

To simplify the calculation of the transistor and the diode currents, the phase current can be assumed to be sinusoidal. The phase current for a motor normally lags the phase voltage by the phase angle $\varphi$. Thus, we define the phase current and the duty cycle according to the following equations.

$$
\begin{gathered}
i_{\varphi}=I_{P} \sin (\theta) \\
d_{Q}=\frac{1}{2}\left[1+m_{a} \sin (\theta+\varphi)\right] .
\end{gathered}
$$

Assuming that the transistor current is fairly constant over one PWM cycle, the average current over that cycle is the current times the duty cycle.

$$
I_{Q, a v e}=\frac{1}{2 \pi} \int_{0}^{\pi} i_{\varphi} d_{Q} d \theta=I_{P}\left(\frac{1}{2 \pi}+\frac{m_{a} \cos \varphi}{8}\right) .
$$

The average diode current may be found in a similar manner.

$$
I_{D, a v e}=\frac{1}{2 \pi} \int_{0}^{\pi} i_{\varphi} d_{D} d \theta=I_{P}\left(\frac{1}{2 \pi}-\frac{m_{a} \cos \varphi}{8}\right) .
$$


The rms currents of the transistor and the diode are found by integrating the current squared times the duty cycle.

$$
\begin{aligned}
I_{Q, r m s} & =I_{P} \sqrt{\left(\frac{1}{8}+\frac{m_{a} \cos \varphi}{3 \pi}\right)} \\
I_{D, r m s} & =I_{P} \sqrt{\left(\frac{1}{8}-\frac{m_{a} \cos \varphi}{3 \pi}\right)} .
\end{aligned}
$$

Then, the conduction losses of the transistors and diodes are calculated by (8) and (9) and depend on the average and the rms values of the current through the valves.

$$
\begin{gathered}
P_{Q, \text { con }}=V_{C E, 0} I_{Q, \text { ave }}+R_{Q, \text { on }} I_{Q, r m s}^{2} \\
P_{D, \text { con }}=V_{F, 0} I_{D, \text { ave }}+R_{D, \text { on }} I_{D, r m s}^{2}
\end{gathered}
$$

where $V_{C E, 0}$ and $V_{F, 0}$ are the threshold voltages and $R_{Q, o n}$ and $R_{D, o n}$ are the on-state resistances of the transistor and the diodes, respectively.

The switching energy is a function of current and varies over the sine wave period. The average switching losses may be found by summing the power loss for each cycle and then dividing by the number of samples.

$$
P_{s w}=\frac{1}{m_{f}} \sum_{n=1}^{m_{f}} P_{c y c}=\frac{1}{m_{f}} \sum_{n=1}^{m_{f}} f_{s w} E_{t o t}(i)
$$

Using a linearized model of the switching losses versus current the switching energy may be expressed as:

$$
E_{\text {tot }}(i)=\frac{E_{\max }}{I_{P}} i_{\varphi}=E_{\max } \sin \theta
$$

The maximum switching energy in this equation is the total switching losses at the peak current of the sine wave. Linear interpolation may be used to find this energy from measured values. A continuous form solution may be found for systems where the carrier is much higher than the sine frequency. Because the current in each transistor is zero for half of the sine period, the integral is again evaluated from zero to $\pi$.

$$
P_{s w}=\frac{1}{2 \pi} \int_{0}^{\pi} f_{s w} E_{\max } \sin \theta d \theta=\frac{f_{s w} E_{\max }}{\pi} .
$$

Thus, the switching losses are directly proportional to the switching frequency.

The power losses of a Z-source inverter can be categorized into six parts: the conduction loss of the transistor during the non-shoot-through states, the switching loss between the non-shoot-through states, the conduction loss of the transistor during the shoot-through state, the switching loss of the shootthrough state, the conduction loss and the reverse recovery loss of the diode during the non-shoot-through states. Therefore, the conduction and switching losses the transistor and the diode change because of the shoot-through states.

From the above discussion, the conduction loss of a ZSI can be expressed as:

$$
\begin{gathered}
P_{Q, \text { con }}=P_{Q, \text { con }, N S T}+P_{Q, \text { con }, S T} \\
P_{D, \text { con }}=P_{D, c o n, N S T}
\end{gathered}
$$

where $P_{Q, c o n, N S T}$ and $P_{Q, c o n, S T}$ are the conduction losses of the transistors during the non-shoot-through states and the shootthrough state, respectively. $P_{D, c o n, N S T}$ is the conduction loss of the diodes during the non-shoot-through states.

Assuming that the shoot-through duty cycle is $D$, the corresponding conduction losses of the transistors and diodes during the non-shoot-through states can be calculated as:

$$
\begin{gathered}
P_{Q, \text { con }, N S T}=(1-D) \cdot\left(V_{C E, 0} I_{Q, \text { ave }}+R_{Q, \text { on }} I_{Q, \text { rms }}^{2}\right) \\
P_{D, \text { con }, N S T}=(1-D) \cdot\left(V_{F, 0} I_{D, \text { ave }}+R_{D, \text { on }} I_{D, r m s}^{2}\right) \\
D=\frac{T_{0}}{T_{s}}=\left(1-\frac{\sqrt{3} m_{a}}{2}\right)
\end{gathered}
$$

where $T_{0}$ is the shoot-through period in a switching cycle $T_{s}$.

It is assumed that the inductor current is high enough so that all transistors conduct during the shoot-through state, the average current through the transistors during the shootthrough is $2 I_{L} / 3$, the conduction loss of the transistors during the shoot-through is [14]:

$$
\begin{gathered}
P_{Q, c o n, S T}=D \cdot V_{C E, 0} \cdot \frac{2}{3} \cdot I_{L} \\
I_{L}=\frac{P_{o}}{V_{\text {in }}}
\end{gathered}
$$

where $V_{\text {in }}$ is the dc input voltage (fuel cell stack).

As mentioned before, the switching loss of the transistors for a Z-source inverter is divided into two parts: the switching loss between the non-shoot-through states, and switching loss of the shoot-through state. The switching loss of the transistor between the non-shoot-through states can be calculated by [14]:

$$
P_{Q, s w, N S T}=\frac{f_{s w} E_{\max }}{\pi}\left(1-\frac{1}{4} \int_{\frac{\pi}{6}-\varphi}^{\frac{5 \pi}{6}-\varphi}|\sin \theta| d \theta\right)
$$

During the shoot-through state, the current from the dc side is $2 I_{L}$. Assuming that the current is evenly distributed among the three phase legs, the average switching current of the shoot-through state is $2 I_{L} / 3$. In each cycle, there are three shoot through switchings, thus the shoot-through switching loss of each transistor is [14]:

$$
P_{Q, s w, S T}=\frac{f_{s w} E_{\max }}{2} .
$$

Since some of the turn-off states of the diodes are turned into shoot-through turn off states, the reverse recovery loss of the diodes is decreased in a way similar to (20).

By using the methods introduced above, the total loss of the inverter bridge can be calculated.

\section{COMPARISON EXAMPLE}

The intention of this paper is to present a comparison of the Z-source inverters for different power semiconductor materials. Hence, a comparison example is conducted with the following specifications:

Maximum power: $50 \mathrm{~kW}$;

Fuel cell voltage at maximum power: $250 \mathrm{~V}$;

Maximum fuel cell output voltage: $420 \mathrm{~V}$; 
Motor power factor (PF) at maximum power: 0.9;

Switching frequency: $10 \mathrm{kHz}$.

The parameters of the motor are as follows:

Peak torque: $240 \mathrm{Nm}$;

Maximum current: $250 \mathrm{~A}$ rms;

Continuous torque: $55 \mathrm{Nm}$;

Continuous power: $34 \mathrm{~kW}$;

Peak efficiency: $93 \%$;

Peak electrical $78 \mathrm{~kW}$ at voltage of $312 \mathrm{Vdc}$;

Nominal speed: $2500 \mathrm{rpm}$;

Maximum speed: 8000 rpm;

Stator leakage inductance: $0.2 \mathrm{mH}$;

Rotor leakage inductance: $0.2 \mathrm{mH}$;

Magnetizing inductance: $3.64 \mathrm{mH}$;

Stator resistance: $11.7 \mathrm{~m} \Omega$;

Rotor resistance: $82 \mathrm{~m} \Omega$;

Corresponding resistance to the core loss: $150 \Omega$.

In the Z-source inverter, the voltage stress of the switches can be calculated by [10]-[14]:

$$
V_{S}=\left(\frac{1}{\sqrt{3} m_{a}-1}\right) V_{i n}
$$

The peak current through the switches occurred at the peak power during the shoot-through state. The peak current through the switch can be expressed as [10]-[14]:

$$
I_{S, \max }=I_{\text {Load }, \max }+\frac{2}{3} I_{L, \max }
$$

where $I_{\text {Load,max }}$ is the maximum load current which occurs at the maximum power and $I_{L, \max }$ is the peak current through the inductor.

For the sake of keeping the voltage stress across the devices at $400 \mathrm{~V}$, the modulation index of the Z-source inverter is considered to be 0.94 based on (22). Hence the peak voltage across the switches and the diode is $400 \mathrm{~V}$ and the maximum current through the switches is $243 \mathrm{~A}$ using (23). It is noted that the current ripple is assumed $60 \%$ of the peak-topeak. Therefore, the devices can be selected for the Z-source inverter. In the following, the devices are selected for Z-source inverter based on three different scenarios: 1 . conventional $\mathrm{Si}$ IGBT modules, 2. hybrid modules, Si IGBTs/SiC Schottky diodes, and 3. SiC MOSFETs/SiC Schottky diodes.

\section{A. Conventional Si IGBT Modules}

Based on the resulting maximum voltage and current, the switches chosen for the ZSI are 600V/300A 6MBP300RA060 IGBT-IPMs, from Fuji Electric [15].

\section{B. Hybrid Modules, Si IGBTs/SiC Schottky Diodes}

Cree has developed 600V/75A SiC Schottky diodes for an ORNL project [8]. Since the ZSI used in this paper has $600 \mathrm{~V} / 300 \mathrm{~A}$, four 75-A SiC Schottky diodes are employed to replace one 300-A Si diode of 6MBP300RA060. For the 75-A $\mathrm{SiC}$ Schottky diode, the forward voltage drop and the series resistance are temperature dependent and their values are given by (24) and (25) [8].

$$
V_{F, 0}=-0.001 \cdot T+0.94
$$

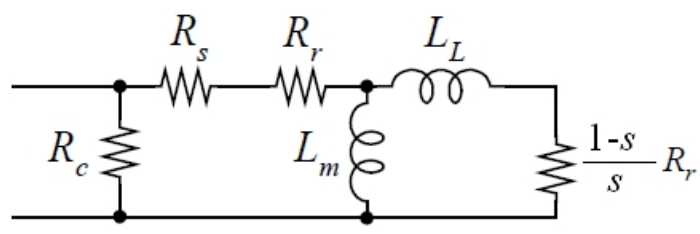

Fig. 3. Simplified model of induction motor.

TABLE I

THE CHARACTERISTICS OF THE SIC-BASED DEVICES

\begin{tabular}{|l|l|}
\hline Transistor on-state resistance & $4.55 \mathrm{~m} \Omega$ \\
Diode on-state resistance & $6.00 \mathrm{~m} \Omega$ \\
Transistor forward voltage & - \\
Diode forward voltage & $0.85 \mathrm{~V}$ \\
Total energy switching loss @ 200A & $11.2 \mathrm{~mJ}$ \\
\hline
\end{tabular}

$$
R_{D, \text { on }}=8.9 \times 10^{-5} \cdot T+0.013
$$

where $T$ is the temperature in degree centigrade.

An experimental test of the energy losses per turn-off of a 75-A SiC Schottky diode shows that the energy losses of the SiC Schottky diodes are negligible [8].

\section{SiC MOSFETs/SiC Schottky Diodes}

In the SiC-based system, the IGBTs are replaced with $\mathrm{SiC}$ MOSFETs and the Si diodes are replaced with SiC Schottky diodes. In the SiC-based drive system, a $1.2-\mathrm{kV} 4 \mathrm{H}-\mathrm{SiC}$ DMOSFET is used as the main power switch. Since commercial SiC MOSFET module data are not currently available, their parameters are calculated by two-dimensional numerical simulations and theoretical analysis [4], [16]. A $1.2 \mathrm{kV} / 20 \mathrm{~A}$ $\mathrm{SiC}$ Schottky diode is used in the SiC-based drive system to replace the Si diode. The parameters are estimated based on the commercially available SiC Schottky diode CSD20120 $(1.2 \mathrm{kV} / 20 \mathrm{~A})$ datasheet. The parameters of the proposed $\mathrm{SiC}$ MOSFETs/SiC Schottky diodes and the IGBT modules are compared in Table I [4].

\section{COMPARISON OF LOSSES AND EFFICIENCY}

A losses and efficiency comparison is conducted based on the specifications of the inverter and the induction motor as introduced above. The operation conditions at different power levels are listed in Table II. The resulting motor currents are also shown in Table II. The semiconductor power losses are calculated using methods introduced in Section III. For the sake of computing the motor losses and efficiency, a simplified model of the motor is employed as shown in Fig. 3, where $R_{C}$ corresponds to the core loss, $R_{s}$ and $R_{r}$ are the stator and rotor resistances, respectively, $I_{m}$ is the magnetizing inductance, $L_{L}$ is the leakage inductance and $\frac{1-s}{s} R_{r}$ corresponds to the output power.

TABLE II

OPERATION CONDITIONS AT DIFFERENT POWER

\begin{tabular}{|c|c|c|}
\hline Power rating & Fuel cell voltage $(\mathrm{V})$ & Motor current $(\mathrm{A})$ \\
\hline $50 \mathrm{~kW} \mathrm{PF}=0.9$ & 250 & 139.6 \\
\hline $40 \mathrm{~kW} \mathrm{PF}=0.85$ & 280 & 113.0 \\
\hline $30 \mathrm{~kW} \mathrm{PF}=0.80$ & 305 & 86.9 \\
\hline $20 \mathrm{~kW} \mathrm{PF}=0.74$ & 325 & 60.9 \\
\hline $10 \mathrm{~kW} \mathrm{PF}=0.70$ & 340 & 31.5 \\
\hline
\end{tabular}




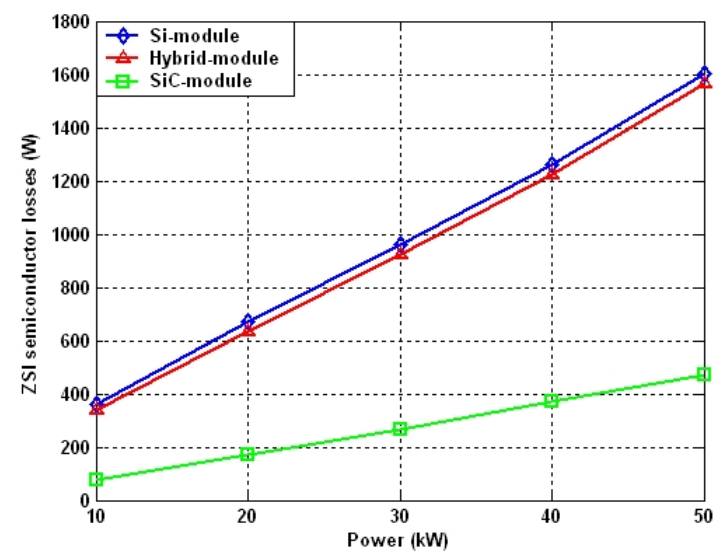

Fig. 4. ZSI semiconductor losses for the investigated scenarios.

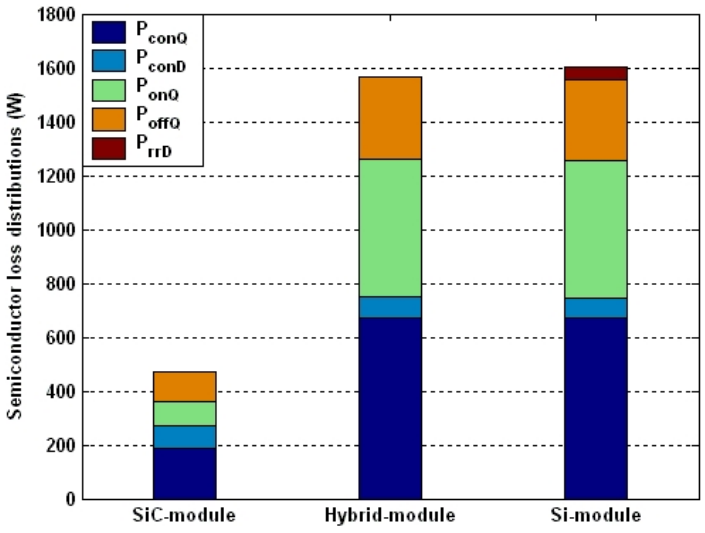

Fig. 5. ZSI semiconductor loss distribution at $P_{o}=50 \mathrm{~kW}$.

Fig. 4 depicts the total ZSI losses as a function of the power in the three investigated scenarios. This figure shows that the ZSI with the SiC-based material features less losses and therefore superior efficiency, compared to the other modules in the three investigated scenarios. The loss distribution of the considered Z-source inverters is shown in Fig. 5 if a power of $P_{o}=50 \mathrm{~kW}$ and a constant carrier frequency of $f_{C}=10 \mathrm{kHz}$ are assumed. It is interesting to note that the Z-source inverter losses of the Si-based IGBT modules and hybrid modules are increased by $238.40 \%$, and $230.28 \%$, compared to the $\mathrm{SiC}$ module. Furthermore, the ZSI with the Si IGBT modules, and the ZSI with the hybrid modules generate $358.88 \%$ and $332.03 \%$ more semiconductor losses, compared to the ZSI with the $\mathrm{SiC}$ modules, if a power of $10 \mathrm{~kW}$ is applied, see Fig. 6. Note that the parameters of the semiconductor devices are considered at junction temperature $T_{j}=125^{\circ} \mathrm{C}$.

The calculated efficiencies of the designed inverters, as well

TABLE III

INVERTER EFFICIENCY COMPARISON

\begin{tabular}{|c|c|c|c|c|c|}
\hline Power $(\mathrm{kW})$ & 10 & 20 & 30 & 40 & 50 \\
\hline Si-module & 96.52 & 96.76 & 96.89 & 96.94 & 96.89 \\
\hline H-module & 96.72 & 96.92 & 97.01 & 97.04 & 96.97 \\
\hline SiC-module & 99.22 & 99.15 & 99.12 & 99.08 & 99.06 \\
\hline
\end{tabular}

TABLE IV

INVERTER-MOTOR SYSTEM EFFICIENCY COMPARISON

\begin{tabular}{|c|c|c|c|c|c|}
\hline Power $(\mathrm{kW})$ & 10 & 20 & 30 & 40 & 50 \\
\hline Si-module & 94.14 & 92.48 & 90.91 & 89.45 & 87.70 \\
\hline H-module & 94.33 & 92.63 & 91.03 & 89.55 & 87.77 \\
\hline SiC-module & 96.77 & 94.77 & 93.01 & 91.43 & 89.66 \\
\hline
\end{tabular}

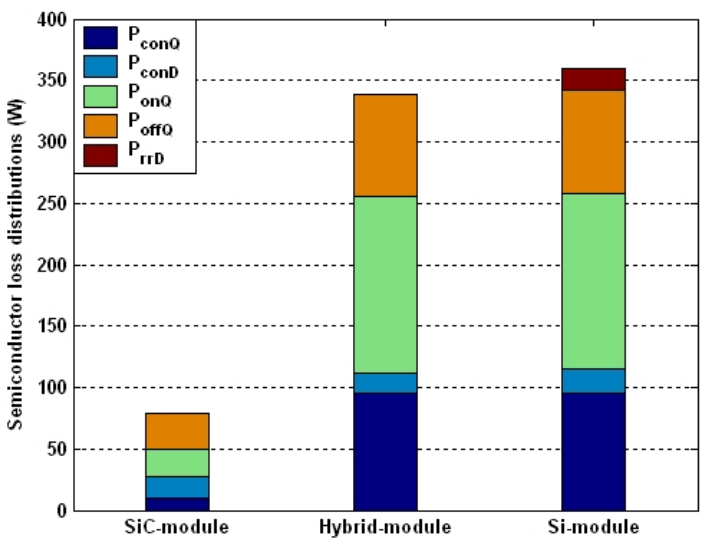

Fig. 6. ZSI semiconductor loss distribution at $P_{o}=10 \mathrm{~kW}$.

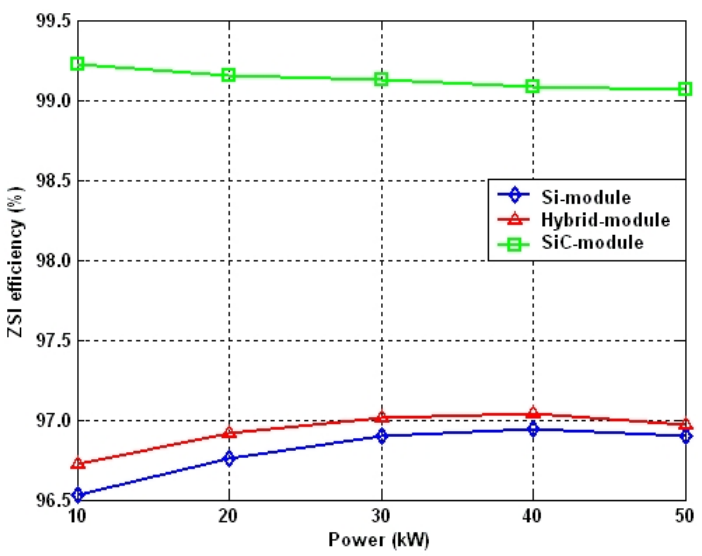

Fig. 7. Calculated efficiency of Z-source inverter.

as those of the inverter-motor system, are listed in Table III and IV, respectively. The calculation results are also plotted in Figs. 7 and 8, respectively. Based on the comparison below, the ZSI with the $\mathrm{SiC}$ materials provides the highest efficiency. This high efficiency can reduce both the thermal requirements and cost.

\section{COMPARISON BETWEEN A Z-SOURCE INVERTER AND A CONVENTIONAL PWM INVERTER}

As previously mentioned, conventional 3-phase PWM inverters are currently being used for FCVs. An efficiency comparison between ZSIs and conventional PWM inverters with $\mathrm{SiC}$ power devices is conducted based on the following conditions: the conventional inverter is always operating at a modulation index of 1 , and the Z-source inverter outputs the maximum obtainable voltage while keeping the switch voltage

TABLE V

INVERTER EFFICIENCY COMPARISON

\begin{tabular}{|l|l|l|l|l|l|}
\hline Power $(\mathrm{kW})$ & 10 & 20 & 30 & 40 & 50 \\
\hline PWM Inverter & 98.71 & 98.64 & 98.61 & 98.56 & 98.54 \\
\hline $\begin{array}{l}\text { Z-Source } \\
\text { Inverter }\end{array}$ & 99.22 & 99.15 & 99.12 & 99.08 & 99.06 \\
\hline
\end{tabular}

TABLE VI

INVERTER-MOTOR SYSTEM EFFICIENCY COMPARISON

\begin{tabular}{|l|l|l|l|l|l|}
\hline Power (kW) & 10 & 20 & 30 & 40 & 50 \\
\hline PWM Inverter & 94.32 & 90.39 & 86.18 & 81.12 & 74.22 \\
\hline $\begin{array}{l}\text { Z-Source } \\
\text { Inverter }\end{array}$ & 96.77 & 94.77 & 93.01 & 91.43 & 89.66 \\
\hline
\end{tabular}




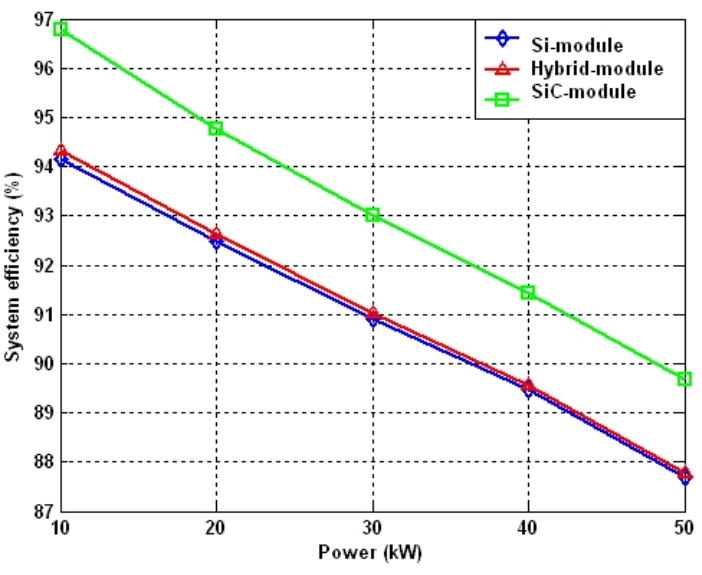

Fig. 8. Calculated efficiency of ZSI-motor system.

under $400 \mathrm{~V}$. The same motor model is used to calculate the motor loss. $1.2 \mathrm{kV}$ SiC MOSFETs/SiC Schottky diodes are selected for each inverter topology as switching devices to calculate their losses. The operation conditions are given in Table II.

The calculated efficiencies of the inverters, as well as those of the inverter plus the motor, are listed in Table $\mathrm{V}$ and VI, respectively. Based on the comparison below, the highest efficiency is archived in the case of using a Z-source inverter.

\section{CONCLUSIONS}

In this paper, a $50 \mathrm{~kW} \mathrm{Z-source} \mathrm{inverter} \mathrm{is} \mathrm{investigated}$ for fuel-cell vehicle application with three different modules: 1. Traditional Si IGBT modules, 2. Hybrid modules, Si IGBTs/SiC Schottky diodes, and 3. SiC MOSFETs/SiC Schottky diodes. The results show that the ZSI with the Si IGBT modules has the biggest losses and that the power loss of the $\mathrm{SiC}$ inverter is about one-third of those for the $\mathrm{Si}$ IGBT inverter. Consequently, the efficiency of the ZSI and the ZSI-motor system with SiC-based devices has the highest efficiency. It can be concluded therefore that the $\mathrm{SiC}$ power devices have the advantages of smaller losses, higher efficiency and smaller size in the same traction drive system of the Zsource inverter for fuel cell vehicles. A comparison between a ZSI and a traditional PWM inverter with $\mathrm{SiC}$ devices also shows that the ZSI produces the highest efficiency.

\section{REFERENCES}

[1] M. O'Keefe and K. Bennion, "A comparison of hybrid electric vehicle power electronics cooling options," in Proc. the Vehicle Power and Propulsion Conference, pp. 116-123, 2007.
[2] C. Mi, F. Z. Peng, K. Kelly, M. O'Keefe, and V. Hassani, "Topology, design, analysis, control, and thermal management of power electronics for electric, hybrid electric, and fuel cell vehicles," International Journal on Hybrid and Electric Vehicles, Vol. 1, No. 3, pp. 276-294, 2008.

[3] B. Ozpineci and L. M. Tolbert, "Characterization of SiC schottky diodes at different temperatures," IEEE Power Electronics Letters, Vol. 1, No. 2, pp. 54-57, Jun. 2003.

[4] T. F. Zhao, J. Wang, A. Q. Huang, and A. Agarwal, "Comparisons of SiC MOSFET and Si IGBT based motor drive systems," in Proc. IAS, pp. 331-335, 2007.

[5] A. Elasser, M. Kheraluwala, M. Ghezzo, R. Steigerwald, N. Krishnamurthy, J. Kretchmer, and T. P. Chow, "A comparative evaluation of new silicon carbide diodes and state-of-the-art silicon diodes for power electronic applications," IEEE Trans. on Ind. Appl., Vol. 39, No. 4, pp. 915-921, Jul./Aug. 2003.

[6] Cree Inc., "Kansai Electric and Cree Demonstrate a 100 kVA Silicon Carbide Three Phase Inverter," 2006.

[7] H. Zhang, L. M. Tolbert, and B. Ozpineci, "System modeling and characterization of $\mathrm{SiC}$ schottky power diodes," in Proc. the IEEE Workshops on Computers in Power Electronics, pp. 199-204, 2006.

[8] B. Ozpineci, M. S. Chinthavali, L. M. Tolbert, A. S. Kashyap, and H. A. Mantooth, "A 55-kW Three-phase inverter with Si IGBTs and SiC schottky diodes," IEEE Trans. Ind. Appl., Vol. 45, No. 1, pp. 278-285, Jan./Feb. 2009.

[9] Cree Inc., "Cree Announces First Power Switch and Diode Co-Pack," 2006.

[10] F. Z. Peng, "Z-Source Inverter," IEEE Trans. Ind. Appl., Vol. 39, No. 2, pp. 504-510, Mar./Apr. 2003.

[11] F. Z. Peng, A. Joseph, J. Wang, M. Shen, L. Chen, Z. Pan, E. OritzRivera, and Y. Huang, "Z-source inverter for motor drives," IEEE Trans. Power Electron., Vol. 20, No. 4, pp. 857-863, Jul. 2005.

[12] M. Shen, J. Wang, A. Joseph, F. Z. Peng, L. M. Tolbert, and D. J. Adams, "Constant boost control of the Z-source inverter to minimize current ripple and voltage stress," IEEE Trans. Ind. Appl., Vol. 42, No. 3, pp. 770-778, May/Jun. 2006.

[13] F. Z. Peng, M. Shen, and K. Holland, "Application of Z-source inverter control for traction drive of fuel cell-battery hybrid electric vehicles," IEEE Trans. Power Electron., Vol. 22, No. 3, pp. 1054-1061, May 2007.

[14] M. Shen, A. Joseph, J. Wang, F. Z. Peng, and D. J. Adams, "Comparison of traditional inverters and Z-source inverter for fuel cell vehicles," IEEE Trans. Power Electron., Vol. 22, No. 4, pp. 1453-1463, Jul. 2007.

[15] Fuji Electric Device Technology, www.fujielectric.co.jp.

[16] L. Reddy, L. M. Tolbert, H. Zhang, and T. Cheek, "Performance of ultra-high efficient electronic ballast for HID lamps using SiC devices," in Proc. IAS, pp. 471-477, 2007.

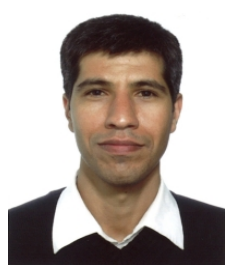

M. Ghasem Hosseini Aghdam was born in Iran in 1978. He received his B.S. from the University of Tabriz, Tabriz, Iran, in 2000 and his M.S. and Ph.D. from the Amirkabir University of Technology (Tehran Polytechnic), Tehran, Iran, in 2003 and 2008, respectively, all in Electrical Engineering. From January 2009 to June 2010, he was employed by the Chalmers University of Technology, Göteborg, Sweden, where he was involved in the design of power electronics converters for electric drive vehicles. He joined Huawei Technologies Sweden AB, Stockholm, Sweden, in June 2010, where he is a Senior Power Electronics Engineer. His research interests include power electronics converter topologies and their control aspects, high power factor single-phase and three-phase rectifiers, power semiconductors, FACTS devises and renewable energy sources. Dr. Hosseini Aghdam is registered as a Professional Engineer in Stockholm, Sweden. He is author or co-author of more than 35 scientific papers published in reviewed journals and presented at international conferences. 